\title{
A computational study of stochastic mechanisms in dendritic calcium spike generation
}

\author{
Haroon Anwar ${ }^{1,2^{*}}$, lain Hepburn ${ }^{1,2}$, Erik De Schutter ${ }^{1,2}$ \\ From Twenty First Annual Computational Neuroscience Meeting: CNS*2012 \\ Decatur, GA, USA. 21-26 July 2012
}

Neuronal activity is largely influenced by voltagedependent and calcium-dependent ion channels, and their interaction with calcium related mechanisms present in and around the complex cellular morphology. In the past, people have focused on stochasticity of voltage-gated ion channels to study its effect on neuronal excitability [1-4] but have ignored the intracellular aspects, in particular calcium dynamics. It is our aim to clarify the role of stochasticity of intracellular calcium dynamics in modulating neuronal output. Intracellular calcium dynamics in neuronal systems significantly control their firing pattern, such as a calcium spike. A calcium spike is generated by interaction of voltage gated $\mathrm{Ca}^{2+}$ channels and $\mathrm{Ca}^{2+}$-activated $\mathrm{K}^{+}$channels, where the interaction is mediated through intracellular calcium mechanisms. A significant proportion of calcium entering through voltage-gated calcium channels binds to buffers, diffuses away and is extruded. Only a limited amount of calcium binds to $\mathrm{Ca}^{2+}$-activated $\mathrm{K}^{+}$channels to conform it to conducting states. These complex interactions take place in and around complex cellular morphology, where stochastic interaction between diffusing molecules and surface bound molecules, stochastic transitions between ion channel conformations and variability in molecular arrangement may have a significant effect on neuronal excitability.

We studied the stochastic behavior of dendritic calcium spikes in Purkinje neurons. In our study, we used a model for dendritic calcium spikes, which included P- and Ttype $\mathrm{Ca}^{2+}$ channels, BK- and SK- type $\mathrm{Ca}^{2+}$-activated $\mathrm{K}^{+}$ channels, parvalbumin and calbindin as calcium buffers, pumps, diffusion of $\mathrm{Ca}^{2+}$ molecules, diffusion of free buffers and diffusion of $\mathrm{Ca}^{2+}$ bound buffers. Details about the

\footnotetext{
* Correspondence: anwar@oist.jp

${ }^{1}$ Computational Neuroscience Unit, Okinawa Institute of Science and

Technology, Okinawa 904-0411, Japan

Full list of author information is available at the end of the article
}

ion channel kinetics, buffer kinetics and diffusion rate constants used in this study can be found in Anwar et al. 2010 [5].We ran all simulations in STEPS [6], which supports stochastic and deterministic molecular simulations alongside accurate computation of the electrical behavior of the cellular region, all within complex 3D morphologies. Therefore we could run a series of stochastic, deterministic and hybrid simulations, investigate the different sources of noise individually and together, and compare to deterministic solutions.

By comparing the sources of noise in this system in absolute and relative terms at different lengths of dendritic section we demonstrate the significance of the different contributing factors to stochasticity in the system, including calcium dynamics and ion channel gating, on a variety of spatial scales.

\section{Author details}

${ }^{1}$ Computational Neuroscience Unit, Okinawa Institute of Science and Technology, Okinawa 904-0411, Japan. ${ }^{2}$ Theoretical Neurobiology, University of Antwerp, B-2610 Antwerpen, Belgium.

Published: 16 July 2012

\section{References}

1. Cannon RC, O'Donnell C, Nolan MF: Stochastic ion channel gating in dendritic neurons: morphology dependence and probabilistic synaptic activation of dendritic spikes. PLoS Comp Biol 2010, 6:e1000886.

2. Careli PV, Reyes MB, Sartorelli JC, Pinto RD: Whole cell stochastic model reproduces the irregularities found in the membrane potential of bursting neurons. J Neurophysiol 2005, 94:1169-1179.

3. Dudmann JT, Nolan MF: Stochastically gating ion channels enable patterned spike firing through activity-dependent modulation of spike probability. PLoS Comp Biol 2009, 5:e1000290.

4. Schneidman E, Freedman B, Segev I: Ion channel stochasticity may be critical in determining the reliability and precision of spike timing. Neural Comput 1998, 10:1679-1703.

5. Anwar H, Hong S, De Schutter E: Controlling Ca(2+)-Activated K (+) Channels with Models of $\mathrm{Ca}(2+)$ Buffering in Purkinje Cells. Cerebellum 2010, DOI: 10.1007/s12311-010-0224-3.

6. STEPS: STochastic Engine for Pathway Simulation. [http://steps. sourceforge.net/].
C Biomed Central

C 2012 Anwar et al; licensee BioMed Central Ltd. This is an Open Access article distributed under the terms of the Creative Commons Attribution License (http://creativecommons.org/licenses/by/2.0), which permits unrestricted use, distribution, and reproduction in any medium, provided the original work is properly cited. 
doi:10.1186/1471-2202-13-S1-P152

Cite this article as: Anwar et al:: A computational study of stochastic mechanisms in dendritic calcium spike generation. BMC Neuroscience 2012 13(Suppl 1):P152.

Submit your next manuscript to BioMed Central and take full advantage of:

- Convenient online submission

- Thorough peer review

- No space constraints or color figure charges

- Immediate publication on acceptance

- Inclusion in PubMed, CAS, Scopus and Google Scholar

- Research which is freely available for redistribution

Submit your manuscript at 